\title{
In vitro antimicrobial properties of Bridelia ferruginea on some clinical isolates
}

\author{
${ }^{1}$ Kareem, Kehinde.T., ${ }^{2}$ Kareem, Sarafadeen.O., ${ }^{2}$ Adeyemo, Omobolaji. J. and \\ ${ }^{1}$ Egberongbe, Rafiat. K. \\ ${ }^{1}$ National Horticultural Research Institute, Ibadan, Oyo State, Nigeria \\ ${ }^{2}$ Department of Microbiology, University of Agriculture, Abeokuta, Ogun State, Nigeria. \\ E-mail address of corresponding author: rabkareem2@yahoo.com \\ Phone no of corresponding author: 08024158641 \\ ABSTRACT
}

\begin{abstract}
Ethanol and water extracts of Bridelia ferruginea were examined for antimicrobial properties. The leaf, bark and root extracts, which were tested from initial concentration of $100 \mathrm{mg} / \mathrm{ml}$ to the final concentration of $6.25 \mathrm{mg} / \mathrm{ml}$, produced invitro antimicrobial activities in assays against clinical isolates of Pseudomonas aeruginosa, Klebsiella pneumoniae, Shigella dysentriae, Proteus mirabilis, Staphylococcus aureus, Hemophilus influenzae, Steptococcus pneumoniae and Escherichia coli. The agar well diffusion method was used to determine the antimicrobial properties of the extracts. The results showed that the growths of the organisms were inhibited by both ethanolic and water extracts of $B$. ferruginea, although the water extracts of plant parts showed significantly lower zones of inhibition. Higher inhibitory effects were seen with the bark and leaf extracts of the plant using ethanol. However, little inhibitory effect was observed in water extracts of the leaves and bark of the plant and no growth was observed with water extract of the root. The minimum inhibitory concentrations (MIC) of the bark extract were 5.5, 10.5, 34.0 and 42.0 for $P$. aeruginosa, $S$. pneumoniae, $H$. influenzae, $K$. pneumoniae, and $P$. mirabilis respectively.
\end{abstract}

Keywords: antimicrobial activities, Bridelia ferruginea, clinical isolates, extract, zones of inhibition

\section{INTRODUCTION}

Despite the existence of potent antibiotics and antifungal agents, resistant or multi-resistant strains are continuously appearing imposing the need for a permanent search and development of new drugs (Silver, 1993). There is an urgent need to systematically evaluate the plants used in traditional medicine. Nowadays, a renewed interest in traditional medicine is observed and there has been an increasing demand for more drugs from plant sources. This revival of interest in plant derived drugs is mainly due to the current widespread belief that "green medicine" is safe and more dependable than costly synthetic drugs many of which have adverse side effects. The need of the hour is to screen a number of medicinal plants for promising biological activity.

Bridelia ferruginea is a common savannah of genus Bridelia. It is usually a gnarled shrub which sometimes reaches the sizes of tree in suitable condition. Their common names are kizni, kirni (Hausa), Mirehi (Fulani), Iroladan (Yoruba), Ola (Igbo), Kensange abia (Boki). Its habitat is the savannah, especially in the moister region extending from Guinea to Zaire and Angola. The tree is $6-15 \mathrm{~m}$ high up to $1.5 \mathrm{~m}$ in girth. The bark is dark grey, rough and often marked scaly (Rashid et al., 2000).

Bridelia ferruginea has diverse uses. A decoction of the leaves has been use to treat diabetes. It is also used as purgative and a vermifuge (Cimanga et al., 1999). The bark has been used for coagulation of milk and lime juice and also for the formulation of a traditional gargle "Ogun efu" (Orafidiya et al., 1990). Kolawole and Olayemi (2003) reported its potential for water treatment. In Togo, the root of the plant is used as chewing stick and root bark is used for intestinal and bladder disorders as well as skin diseases (De Bruyne et al., 1997). Other reported activities of the bark extract include molluscidal (Iwu, 1984); antimicrobial (Adeoye et al., 1988) and antiinflammatory (Olajide et al., 1999). B. ferruginea has been found to contain various organic compounds according to Sofowora (1977). The plant was found to contain Alkaloids, Tannins, Terpenoids, Glycosides, Flavonoids, Saponins, Anthraquinones and Steroids.

Literature reports and ethnobotanical records suggest that plants are the sleeping giants of pharmaceutical 
industry (Hostettman and Hamburger, 1991). They may provide natural source of antimicrobial drugs that will provide novel compounds that may be employed in controlling some infections globally. In view of this, the objective of this study is to investigate the antimicrobial properties of the leaf, bark and root of $B$. ferruginea.

\section{MATERIALS AND METHODS}

Collection and processing of Plant Samples: Fresh leaf, bark and root samples of $B$. ferruginea were collected at Camp, Abeokuta, Ogun State, Nigeria. The plant was identified at the Department of Biological Sciences (Botany option), University of Agriculture, Abeokuta.

The samples were dried at $60^{\circ} \mathrm{C}$ for few minutes until they became crispy and were ground into powder. The samples were stored in air tight containers for further use.

Preparation of Plant Extract: The ground leaf sample was extracted with water and $50 \%$ ethanol. $5 \mathrm{~g}$ of the sample was added to $50 \mathrm{ml}$ of either ethanol or water to obtain $100 \mathrm{mg} / \mathrm{ml}$ concentration. Other concentrations obtained include $50 \mathrm{mg} / \mathrm{ml}(2.5 \mathrm{~g}$ in $50 \mathrm{ml}) ; 25 \mathrm{mg} / \mathrm{ml}(1.25 \mathrm{~g}$ in $50 \mathrm{ml}) ; 12.5 \mathrm{mg} / \mathrm{ml}$ $(0.625 \mathrm{~g}$ in $50 \mathrm{ml})$ and $6.25 \mathrm{mg} / \mathrm{ml}(0.3125 \mathrm{~g}$ in $50 \mathrm{ml})$.

Both the ground bark and root samples were extracted with water and $50 \%$ ethanol. The concentrations were generated as done in leaf extraction.

In each of the three cases above, the solution was filtered using Whatmann No 1 filter paper after it was allowed to stand overnight.

Source of Test Organisms: Eight clinical isolates including; Klebsiella pneumoniae, Escherichia coli, Shigella dysentriae, Staphylococcus aureus, Streptococcus pneumoniae, Hemophilus influenzae, Pseudomonas aeruginosa and Proteus mirabilis were obtained from University College Hospital, Ibadan. The isolates were further identified in the laboratory using the standard biochemical test and subcultured on appropriate media in slants, incubated for 24 hours and kept at $4^{\circ} \mathrm{C}$ until they were needed.

Evaluation of Antimicrobial Activity of $B$. ferruginea: The antimicrobial assay was performed by agar well diffusion method according to Perez, et al. (1990) for both aqueous and ethanol extraction. Chocolate agar was used for Haemophilus influenzae and Streptococcus pneumoniae while nutrient agar was used for the other six organisms. Equal volume of the extract was transferred into wells made on the agar. The plates were allowed to stand for one hour to allow for pre-diffusion of the extract into the medium. (Esimone et al., 1998). The plates were incubated at $37^{\circ} \mathrm{C}$ for 24 hours. At the end of the incubation, zones of inhibition that developed were measured in centimetre and later converted to millimeter.

Evaluation of the Minimum Inhibitory Concentration: According to Esimone et al. (1998) and as adopted in this study, the minimum inhibitory concentration (MIC) was calculated by plotting a graph of the natural logarithm of the concentration of the extract against the square of the zone of inhibition and a regression line drawn through the points. The antilogarithm of the intercept on the natural logarithm of concentration axis therefore gave the MIC value.

Statistical Analysis: The data obtained from the experiment was analyzed using the Statistical Package for Social Sciences (SPSS). Descriptive statistics was used to determine the mean and standard error.

\section{RESULTS AND DISCUSSION} RESULTS

Table 1 showed that the ethanol extract of the leaves of $B$. ferruginea has a wider range of inhibitory effect than the water extract. At $100 \mathrm{mg} / \mathrm{ml}$, only the growth of $S$. aureus and $E$. coli were not inhibited by the extract. Other isolates were inhibited to varying degree at the same concentration. However, the effect of extract on $H$. influenzae and S. pneumoniae was not significantly different at this concentration. Meanwhile, at $50 \mathrm{mg} / \mathrm{ml}$, marked difference was observed between these two organisms (Table 1). At $50 \mathrm{mg} / \mathrm{ml}$ and $100 \mathrm{mg} / \mathrm{ml}$, the growth of $P$. mirabilis and $S$. aureus were inhibited by the water extract of the leaf while the other organisms were not affected by the extract at this same concentration. Both the ethanol and water extracts of the leaves of the plant at $6.25 \mathrm{mg} / \mathrm{ml}$ were not effective against the isolates. Moreso, the growth of $E$. coli was not affected by either the ethanol or water extracts of the leaf. $K$. pneumoniae, $H$. influenzae, S. pneumoniae, and $P$. aeruginosa were not susceptible to the water extract of the leaf at all the concentrations used (Table 1).

The growth of $S$. pneumoniae was inhibited by the ethanolic extract of the bark of the plant at all the concentrations used in this study. However, the growth of S. dysentriae and S. aureus were not affected by this extract. E. coli was susceptible only at $50 \mathrm{mg} / \mathrm{ml}$ with a mean value of $5.00 \mathrm{~mm}$. Significantly higher mean value of $10.0 \mathrm{~mm}$ was obtained for both $\mathrm{S}$. pneumoniae and $\mathrm{H}$. influenzae at 
$6.25 \mathrm{mg} / \mathrm{ml}$ and $25 \mathrm{mg} / \mathrm{ml}$ respectively. Isolates were not susceptible to the water extract of the bark at $6.25 \mathrm{mg} / \mathrm{ml}, 12.5 \mathrm{mg} / \mathrm{ml}$ and $100 \mathrm{mg} / \mathrm{ml}$. Whereas, the growth of $P$. mirabilis and $S$. dysentariae were inhibited at $25 \mathrm{mg} / \mathrm{ml}$ and $50 \mathrm{mg} / \mathrm{ml}$ of the same extract with mean values between the range of $4.33 \mathrm{~mm}$ and $12.00 \mathrm{~mm}$ (Table 2).

Significantly lower value of $2.67 \mathrm{~mm}$ was obtained at 25 and $50 \mathrm{mg} / \mathrm{ml}$ for S. pneumoniae. On the other hand, $4.0 \mathrm{~mm}$ was obtained for the same organism at other concentrations when the root was extracted with ethanol. The values of the zones of inhibition

Table 1. Antimicrobial assay of leaves of Bridelia ferruginea on isolates

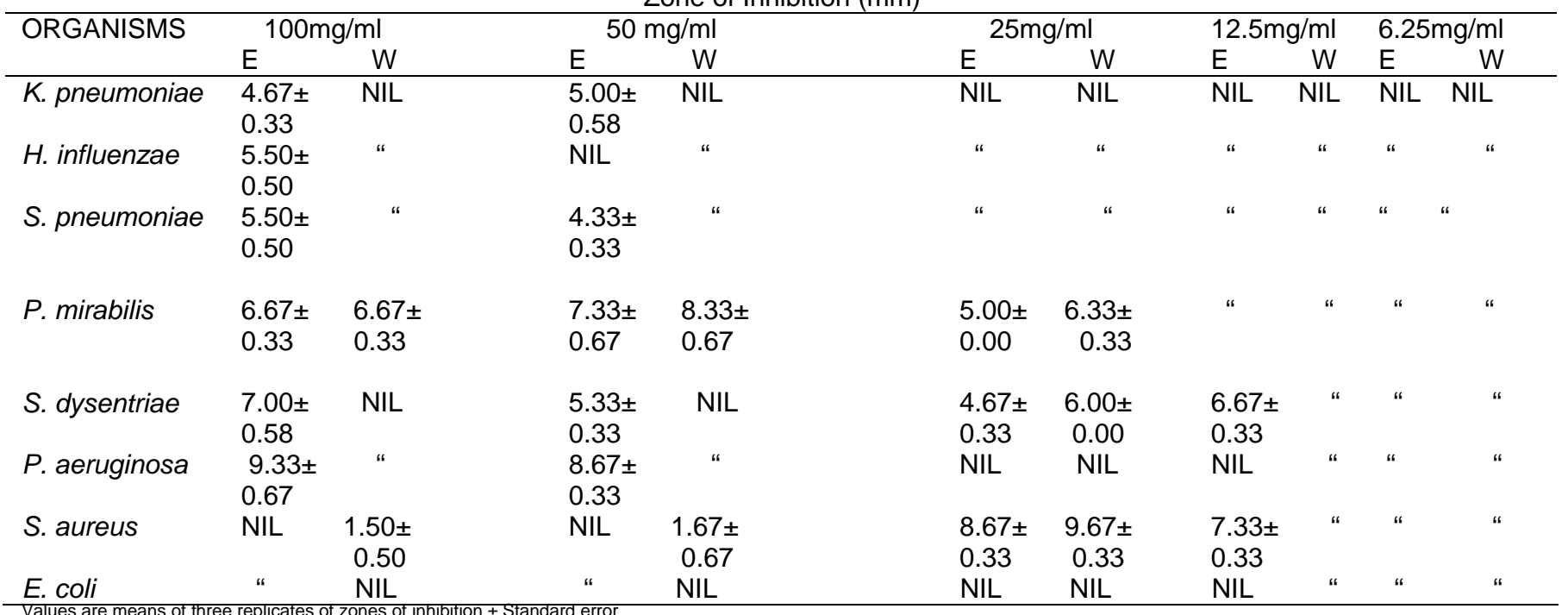

$\mathrm{E}=\mathrm{Ethanolic}$ extract; $\mathrm{W}=$ Water extract.

Table 2. Antimicrobial assay of bark of Bridelia ferruginea on isolates

\begin{tabular}{|c|c|c|c|c|c|c|c|c|c|c|}
\hline \multicolumn{11}{|c|}{ Zone of Inhibition (mm) } \\
\hline \multirow[t]{2}{*}{ ORGANISMS } & \multicolumn{2}{|c|}{$100 \mathrm{mg} / \mathrm{ml}$} & \multicolumn{2}{|c|}{$50 \mathrm{mg} / \mathrm{ml}$} & \multicolumn{2}{|c|}{$25 \mathrm{mg} / \mathrm{ml}$} & \multicolumn{2}{|c|}{$12.5 \mathrm{mg} / \mathrm{ml}$} & \multicolumn{2}{|c|}{$6.25 \mathrm{mg} / \mathrm{ml}$} \\
\hline & $E$ & W & $E$ & W & $E$ & W & $E$ & W & $E$ & W \\
\hline K. pneumoniae & $\begin{array}{l}8.33 \pm \\
0.33\end{array}$ & NIL & $\begin{array}{l}8.50 \pm \\
0.50\end{array}$ & " & NIL & NIL & NIL & NIL & NIL & " \\
\hline H. influenzae & $\begin{array}{l}6.00 \pm \\
1.00\end{array}$ & “ & $\begin{array}{l}10.50 \pm \\
0.50\end{array}$ & " & $\begin{array}{l}10.00 \pm \\
0.00\end{array}$ & “ & $\begin{array}{l}8.33 \pm \\
1.76\end{array}$ & “ & NIL & “ \\
\hline S. pneumoniae & $\begin{array}{l}6.00 \pm \\
0.58\end{array}$ & “ & $\begin{array}{l}8.67 \pm \\
0.88\end{array}$ & “ & $\begin{array}{l}5.67 \pm \\
0.88\end{array}$ & “ & $\begin{array}{l}8.00 \pm \\
2.00\end{array}$ & “ & $\begin{array}{l}10.00 \pm \\
0.00\end{array}$ & “ \\
\hline S. dysentriae & NIL & “ & NIL & $\begin{array}{c}4.67 \pm \\
0.67\end{array}$ & “ & $\begin{array}{c}4.33 \pm \\
0.33\end{array}$ & “ & “ & “ & “ \\
\hline$P$. aeruginosa & “ & “ & “ & “ & $\begin{array}{l}8.00 \pm \\
0.58\end{array}$ & NIL & $\begin{array}{l}3.67 \pm \\
0.67\end{array}$ & “ & $\begin{array}{l}5.67 \pm \\
0.67\end{array}$ & “ \\
\hline S. aureus & “ & “ & “ & “ & NIL & “ & NIL & “ & NIL & “ \\
\hline
\end{tabular}

Values are means of three replicates of zones of inhibition \pm Standard error

$\mathrm{E}=\mathrm{Ethanolic}$ extract; $\mathrm{W}=\mathrm{Water}$ extract.

produced by $H$. influenza ranged between $3.33 \mathrm{~mm}$ and $4.0 \mathrm{~mm}$. $P$. aeruginosa produced zones of clearance at 12.5 and $25 \mathrm{mg} / \mathrm{ml}$ while other organisms were not affected by the ethanolic extract of the root. None of the isolates was susceptible to the water extract of the root of $B$. ferruginea (Table 3 ).

The minimum inhibitory concentrations of all the extracts used are shown in table 4 . The MIC of the bark extract ranged between 5.5 and $42.0 \mathrm{mg} / \mathrm{ml}$ while that of leaf extract was between 10.0 to $82.5 \mathrm{mg} / \mathrm{ml}$.

Zone of Inhibition $(\mathrm{mm})$ 
Agric. Biol. J. N. Am., 2010, 1(3): 416-420

Table 3. Antimicrobial assay of root of Bridelia ferruginea on isolates

Zone of Inhibition ( $\mathrm{mm}$ )

\begin{tabular}{|c|c|c|c|c|c|c|c|c|c|c|}
\hline ORGANISMS & \multicolumn{2}{|c|}{$100 \mathrm{mg} / \mathrm{ml}$} & \multicolumn{2}{|c|}{$50 \mathrm{mg} / \mathrm{ml}$} & \multicolumn{2}{|c|}{$25 \mathrm{mg} / \mathrm{ml}$} & \multicolumn{2}{|c|}{$12.5 \mathrm{mg} / \mathrm{ml}$} & \multicolumn{2}{|c|}{$6.25 \mathrm{mg} / \mathrm{ml}$} \\
\hline & $E$ & W & $E$ & W & E & W & $E$ & W & E & W \\
\hline K. pneumoniae & NIL & NIL & NIL & NIL & NIL & NIL & NIL & NIL & NIL & NIL \\
\hline H. influenzae & $3.33 \pm 0.67$ & " & $4.00 \pm 0.58$ & “ & $3.67 \pm 0.33$ & “ & $3.67 \pm 0.33$ & " & $4.00 \pm 0.00$ & “ \\
\hline S. pneumoniae & $4.00 \pm 0.58$ & “ & $2.67 \pm 0.33$ & “ & $2.67 \pm 0.67$ & “ & $4.00 \pm 0.00$ & “ & $4.00 \pm 0.00$ & “ \\
\hline P. mirabilis & NIL & “ & NIL & “ & NIL & “ & NIL & “ & NIL & “ \\
\hline S. dysentriae & “ & “ & “ & “ & “ & “ & “ & “ & “ & “ \\
\hline$P$. aeruginosa & “ & “ & “ & " & $9.67 \pm 0.33$ & “ & $4.33 \pm 0.33$ & “ & “ & “ \\
\hline S. aureus & “ & “ & “ & “ & NIL & “ & NIL & “ & “ & " \\
\hline E. coli & “ & “ & “ & “ & “ & “ & “ & “ & “ & “ \\
\hline
\end{tabular}

$\mathrm{E}=$ Ethanolic extract; $\mathrm{W}=\mathrm{Water}$ extract.

Table 4. Minimum Inhibitory Concentrations of Plant Extracts ( $\mathrm{mg} / \mathrm{ml})$

\begin{tabular}{|l|l|l|l|l|l|l|l|}
\hline & K.pneumoniae & H.influenzae & S.pneumoniae & $\begin{array}{l}\text { P. } \\
\text { mirabilis }\end{array}$ & S.dysentriae & P.aeruginosa & S. aureus \\
\hline $\begin{array}{l}\text { Leaf water } \\
\text { extract }\end{array}$ & - & - & - & 24.0 & 10.5 & - & 10.0 \\
\hline $\begin{array}{l}\text { Leaf } \\
\text { ethanol } \\
\text { extract }\end{array}$ & 45.0 & 82.5 & 43.5 & 23.6 & 22.0 & 30.3 & 32.2 \\
\hline $\begin{array}{l}\text { Bark } \\
\text { ethanol } \\
\text { extract }\end{array}$ & 34.0 & 10.5 & 5.5 & -42.0 & - & 5.5 & - \\
\hline $\begin{array}{l}\text { Bark water } \\
\text { extract }\end{array}$ & - & - & - & 20.8 & 19.5 & - & - \\
\hline $\begin{array}{l}\text { root ethanol } \\
\text { extract }\end{array}$ & - & 6.0 & 5.8 & - & - & 12.5 & - \\
\hline
\end{tabular}

- = isolate not susceptible to extract

\section{DISCUSSION}

The present study revealed that the bacterial isolates used were susceptible to both the ethanolic and water extracts of Bridelia ferruginea at varying degree using agar well diffusion method, although the effect of water extract was not as much as that of ethanol. This indicates that ethanol is the best extractive solvent for the extraction of $B$. ferruginea. This is in agreement with the work of Kareem et al., 2008, which stated that ethanol is the best extractive solvent for extracting antimicrobial substances in plants.

The potency of $B$. ferruginea to inhibit the growth of the pathogens can be traced to the presence of some active ingredients in the plant. This corroborates the work of Sofowora (1977), which indicated that $B$. ferruginea contains tannins, glycosides, steroids, saponins, terpenoids, flavonoids and anthraquinones. He further stated that these compounds are known to be biologically active.

No zones of inhibition were observed with water extracts of plant parts against Pseudomonas aeruginosa but this result was not strange since resistance of Pseudomonas aeruginosa to most antibacterial agents is well known (Irvin et al., 1981). This can be due to the fact that the organism may possess a mechanism for detoxifying the active principles in the extract. Some bacteria are known to possess mechanism by which they convert substances that inhibit their growth to non-toxic compounds. For example, Staphylococcus aureus produce the enzyme penicillinase which converts the antibiotic penicillin to penicillinoic acid, which is no longer inhibitory to its growth. (Singleton, 1999).

The bark and the root extracts of $B$. ferruginea were highly effective against $H$. influenzae and $S$. pneumoniae and these two organisms are microflora of the oral cavity. This statement is in conformity with the work of Sofowora (1993) who reported that the plant has been used as a mouthwash in Africa. Moreso, Orafidiya et al. (1990) reported that the bark of $B$. ferruginea has been used for the formulation of a traditional gargle "Ogun efu". De Bruyne et al. (1997) also reported the use of the root of the plant as chewing sticks in Togo. 
The antimicrobial properties of $B$. ferruginea observed in this study are a confirmation of its wide use in traditional medicine. The extracts of the plant have shown antimicrobial activities against microorganisms commonly known to cause enteric and secondary upper respiratory tract infection. This statement is substantiated by the work of De Bruyne et al. (1997), who reported that the root and bark of $B$. ferruginea are used for intestinal and bladder disorders as well skin diseases.

\section{REFERENCES}

Adeoye, A.O, Abaeli, A.M, Owowumi, C.J, Olukoya, D.K (1988). Antimicrobial activity of Bridelia ferruginea in: Book of Abstract of the symposium on drug production from natural products. Drug Research and Production Unit, Obafemi Awolowo University, Ile-Ife, 24.

Cimanga, K., De Bruyne, T., Apers, S., Dieters, L., Totte, J., Kambu, K., Tona, L., Bakana, P., Van Ufford, L.Q., Beukelman, C., Labadie, R. and Vlietinck, A.J. (1999). Complement- inhibiting constituents of Bridelia ferruginea stem bark. Planta Med. 65:213-217.

De Bruyne, T., Cimanga, K., Pieters, L., Claeys, M., Dommisse, R. and Vlietinck, A. (1997). Gallocatechim (4-0-7) - Epigallocatechin. A new Biflavonoid isolated from Bridelia ferruginea. Nat. Prod. Let. 11:47-52.

Esimone, C.O., Adiuku, M.U. and Okonta, J.M. (1998). Preliminary Antimicrobial Screening of the Ethanolic Extract from the Lichen Usnea subfloridans (L). J. Pharmaceutic Res. Dev. 3(2): 99-102.

Hostettmann, K. and Hamburger, M. (1991). Medicinal Plants in Tropical West Africa. Phytochem. 30(12): 3864-3874.

Irvin, R.T., Govan, J.R.Q., Fyfe, J.A.M.and Costerton, J.W. (1981).Heterogeneity of antibiotic Resistance in Mucoid Isolates of Pseudomonas aeruginosa obtained from cystic fibrosis patients: Role of outer membrane proteins. Antimicrobial Agents and Chemotherapy. 19: 1056-1063.
Iwu, M.M. (1984). In proceedings of 4th Annual Conference of Nigeria Society of Pharmacognosy, University of Nigeria, Nsukka, In: The State of Medicinal Plant Research in Nigeria. A. Sofowora ed.pp 57.

Kareem, S.O., Akpan, I. and Ojo, O.P. (2008). Antimicrobial Activities of Calotropis procera on Selected Pathogenic Microorganisms. Afr J Biomed Res. 11:105-110

Kolawole, O.M. and Olayemi, A.B. (2003). Studies on the efficacy of Bridelia ferruginea benth bark extract for water purification. Nig. J. Pure Appl. Sci. 18: 13871394

Olajide, O.A., Makinde, J.M. and Awe, S.O. (1999). Effect of aqueous extract of Bridelia ferruginea stem bark corrageenan - induced oedema and granuloma tissue formation in rats and mice. J. Ethnopharmacol. 66(1): 113-117.

Orafidiya, L.O., Lamikanra, A. and Adediji, J.A. (1990). Phytotherapy Research (United Kingdom). 4(5):189194.

Perez, C., Paul, M., Bazerque, P. (1990). An Antibiotic assay by the agar well diffusion method. Acta. Bio. Med. Exp. 15: 113-115.

Rashid, M.A., Gustafson, K.R., Cardellina, J.H. and Boyd, M.R. (2000). A New podophyllotoxin Derivative from Bridelia ferruginea. Nat. Prod. Let. 14: 285-292.

Silver, L.L. (1993). Discovery and development of new antibiotics: the problem of antibiotic resistance. Antimicrob. Agents Chemother. 37: 377-383.

Singleton, P. (1999). Bacteria in Biology, Biotechnology and Medicine, $4^{\text {th }}$ edition. John Wiley and sons Ltd. New York.

Sofowora, E.A. (1977). Screening Plants and traditional medicine in Africa. 142-144.

Sofowora, E.A. (1993). Medicinal Plants and Traditional Medicine in Africa. $2^{\text {nd }}$ edition. Spectrum Books Limited. pp 289 